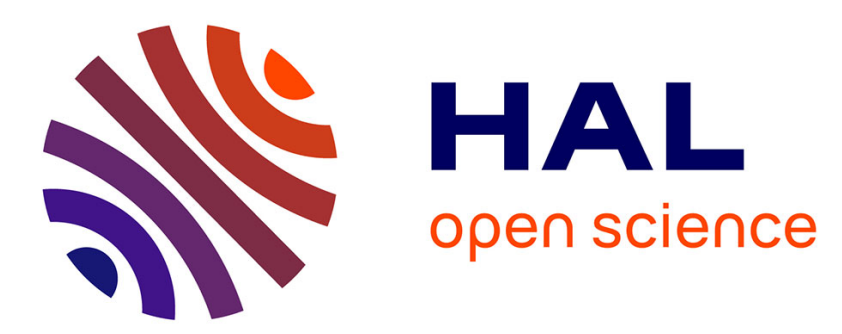

\title{
Epitaxial Growth of $\alpha$-Fe2O3 and Cr2O3 Sputtered Films on Garnet
}

\author{
M. Gomi, H. Toyoshima, T. Yamada
}

\section{To cite this version:}

M. Gomi, H. Toyoshima, T. Yamada. Epitaxial Growth of $\alpha$-Fe2O3 and $\mathrm{Cr} 2 \mathrm{O} 3$ Sputtered Films on Garnet. Journal de Physique IV Proceedings, 1997, 07 (C1), pp.C1-481-C1-482. 10.1051/jp4:19971195 . jpa-00254845

\section{HAL Id: jpa-00254845 https://hal.science/jpa-00254845}

Submitted on 1 Jan 1997

HAL is a multi-disciplinary open access archive for the deposit and dissemination of scientific research documents, whether they are published or not. The documents may come from teaching and research institutions in France or abroad, or from public or private research centers.
L'archive ouverte pluridisciplinaire HAL, est destinée au dépôt et à la diffusion de documents scientifiques de niveau recherche, publiés ou non, émanant des établissements d'enseignement et de recherche français ou étrangers, des laboratoires publics ou privés. 


\title{
Epitaxial Growth of $\alpha-\mathrm{Fe}_{2} \mathrm{O}_{3}$ and $\mathrm{Cr}_{2} \mathrm{O}_{3}$ Sputtered Films on Garnet
}

\author{
M. Gomi, H. Toyoshima and T. Yamada \\ Department of Materials Science, Japan Advanced Institute of Science and Technology, 1-1 Asahidai, \\ Tatsunokuchi, Ishikawa 923-12, Japan
}

\begin{abstract}
Thin films of $\alpha-\mathrm{Fe}_{2} \mathrm{O}_{3}$ and $\mathrm{Cr}_{2} \mathrm{O}_{3}$ have been prepared in situ on gadolinium gallium garnet (GGG) (111) substrates by rf sputtering. The $\alpha-\mathrm{Fe}_{2} \mathrm{O}_{3}$ film showed a strong [0006] texture normal to the film plane at $500^{\circ} \mathrm{C}$ when deposited on an initial layer with $7-10 \mathrm{~nm}$ thick grown at ambient temperature, while the $\mathrm{Cr}_{2} \mathrm{O}_{3}$ films with a [0006] texture grew in pure Ar without the initial layer. X-ray pole figure analysis showed that nearly single crystalline (0001) films of $\alpha$ $\mathrm{Fe}_{2} \mathrm{O}_{3}$ and $\mathrm{Cr}_{2} \mathrm{O}_{3}$ were grown on GGG (111) with an in-plane alignment of [21i0] parallel to GGG [110]. Thus, these films with the corundum crystal structure may be a promising buffer layer for achieving heteroepitaxy of various ferrite thin films onto a common substrate of GGG.
\end{abstract}

\section{INTRODUCTION}

Epitaxial film growth of ferrite such as yttrium iron garnet and Ba-hexaferrite onto a common substrate is of great importance for realizing microwave monolithic integrated circuit with high performance. It has been recently shown that Ba hexaferrite films can be epitaxially grown on basal plane sapphire with the corundum structure [1]. However, few studies on heteroepitaxy of the ferrite thin films have been reported so far. This is because there are few substrate crystals closely lattice matched to the ferrites with complicated crystal structures. Thus, buffer layer which provides a close structural fit with both of the substrate and the ferrite film is indispensable to achieve the heteroepitaxy.

We have recently reported that epitaxial thin films of $\alpha-\mathrm{Fe}_{2} \mathrm{O}_{3}$ with the corundum structure can be fabricated by sputtering and subsequent annealing on gadolinium gallium garnet (GGG) which is a widely used substrate for the epitaxial growth of garnet films [2].After that, we have successfully attained in situ growth of nearly single-crystalline films of $\alpha-\mathrm{Fe}_{2} \mathrm{O}_{3}$ and $\mathrm{Cr}_{2} \mathrm{O}_{3}$ on GGG. Since these films have lattice constants close to that of the sapphire, they may be applied to a buffer layer which allows both of the Ba hexaferrite film and the iron garnet film to epitaxially grow onto a common substrate of GGG crystal. In this paper, we describe the conditions of in situ growth of their films and reveal crystallographic orientation relationships between the films and the substrate.

\section{FILM GROWTH}

The films were deposited on (111)-oriented GGG single crystal substrates by $\mathbf{r f}$ diode sputtering using sintered ceramic targets of $\alpha-\mathrm{Fe}_{2} \mathrm{O}_{3}$ and $\mathrm{Cr}_{2} \mathrm{O}_{3}$. The if power density was kept at $8 \mathrm{~W} / \mathrm{cm}^{2}$ which gives a deposition rate of $3-4 \mathrm{~nm} / \mathrm{min}$. The mixture gas of $\mathrm{Ar}$ and $\mathrm{O}_{2}$ was used as a sputtered gas. The substrate was heated up to $500^{\circ} \mathrm{C}$ at maximum. When the film was deposited at ambient temperature, the substrate temperature $T_{s}$ rose up to about $180^{\circ} \mathrm{C}$ due to plasma.

\section{RESULTS AND DISCUSSION}

Figure 1 shows typical X-ray diffraction spectra for the $\alpha-\mathrm{Fe}_{2} \mathrm{O}_{3}$ films prepared under several substrate temperatures and gas pressures ( partial pressure of $\mathrm{O}_{2}: 10 \%$ ). For deposition at high temperature, the spectra of the films show the diffraction peaks from $(11 \overline{2} 0),(0006)$ and $(11 \overline{2} 3)$ planes, while the films deposited at ambient temperature have a single peak from $(11 \overline{2} 0)$ plane for the gas pressure of $50 \mathrm{~m}$ Torr and $(0006)$ plane for 10 mTorr. The peak seen around $37.6 \mathrm{deg}$ in the spectrum at $50 \mathrm{mTorr}$ is identified with that from (222) plane of $\gamma-\mathrm{Fe}_{2} \mathrm{O}_{3}$ which was made by insufficient oxidization of sputtered $\mathrm{Fe}$ ions on the substrate. These diffraction peaks are weak and broad, reflecting poor crystallinity of the films. No films with a strong texture were directly obtained under the sputtering conditions used.

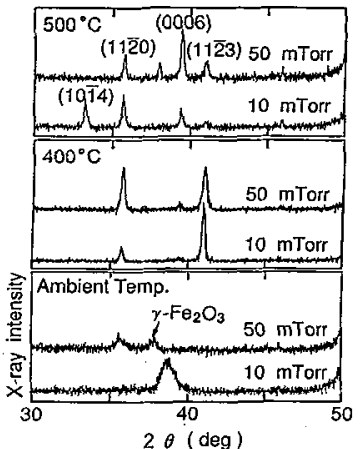

Fig. 1 Typical $\mathrm{X}$-ray diffraction spectra of $\alpha-\mathrm{Fe}_{2} \mathrm{O}_{3}$ sputtered films. 


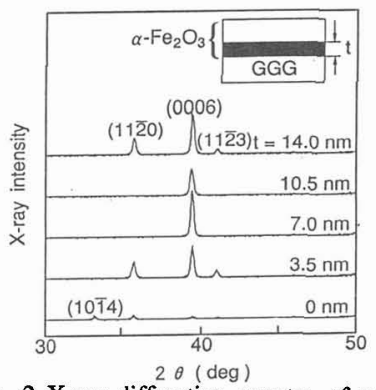

Fig. $2 \mathrm{X}$-ray diffraction spectra of $\alpha-\mathrm{Fe}_{2} \mathrm{O}_{3}$ layers $\left(\mathrm{T}_{\mathrm{s}}=500^{\circ} \mathrm{C}\right)$ on the underlying layers with thickness $t$ deposited at $10 \mathrm{~m}$ Torr and ambient temperature.

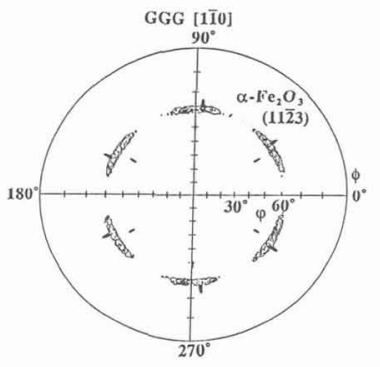

Fig. $3 X$-ray pole figure taken from the $(11 \overline{2} 3)$ peak of $\alpha-\mathrm{Fe}_{2} \mathrm{O}_{3}$ film which was grown on the initial layer with $7 \mathrm{~nm}$ thick.

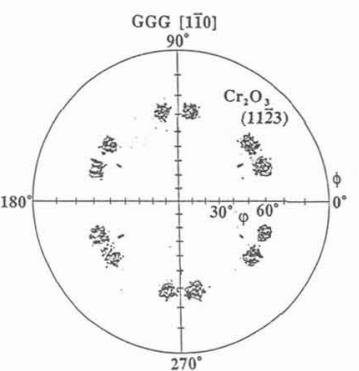

Fig. $4 \mathrm{X}$-ray pole figure of $\mathrm{Cr}_{2} \mathrm{O}_{3}$ film with a prominent [0006] texture, which was taken from the (1153) diffraction peak.

To in situ grow the films with a strong [0001] texture normal to the film plane, a two-step deposition process, which involved an initial growth of $\alpha-\mathrm{Fe}_{2} \mathrm{O}_{3}$ at ambient temperature followed by growth at $500^{\circ} \mathrm{C}$, was tried. Both growths were done under a gas pressure of $10 \mathrm{~m}$ Torr. Figure 2 shows relationship between the crystal orientation of the overlying layer and the thickness $t$ of the underlying layer. At $t<3.5 \mathrm{~nm}$ and $\mathrm{t}>14 \mathrm{~nm}$, the films are polycrystalline with no preferred crystal orientation, as well as the film without underlying layer, while, when $t=7 \mathrm{~nm}$ and $10.5 \mathrm{~nm}$, the films showed a strong [0006] texture. Figure 3 shows pole figure taken from the $(11 \overline{2} 3)$ peak of the $\alpha-\mathrm{Fe}_{2} \mathrm{O}_{3}$ film which was grown on the initial layer with $7 \mathrm{~nm}$ thick. It exhibits six pole densities every $60^{\circ}$ for $\phi$ scans at $\varphi=61^{\circ}$, similar to that for the epitaxial film obtained by heat treatment previously [2]. The width of the pole density in $\phi$ scans are rather broad, indicating substantial twist misalignment of the grains. These make an angle of about $30^{\circ}$ in $\phi$ scans with the pole densities of the substrate taken from the (440) diffraction peak. Other narrow spots with the strongest intensity simultaneously observed, are due to reflections from the substrate. The results obtained from pole-figure analysis indicate that a nearly single-crystalline film of (0001)-oriented $\alpha-\mathrm{Fe}_{2} \mathrm{O}_{3}$ was in situ grown on GGG (111) with an in-plane alignment of $\alpha-\mathrm{Fe}_{2} \mathrm{O}_{3}$ [2110] parallel to GGG [110]. These results are explained by assuming that, when $\mathrm{T}_{\mathrm{s}}$ rose above $500^{\circ} \mathrm{C}$, the thin initial layer having an appropriate thickness is recrystallized and the inplane alignment in the layer traces the surface potential of the substrate to reduce the film-substrate interface energy: Too thin initial layer which incompletely covers the surface of the substrate, or too thick initial layer in which in-plane crystalline reorientation would not occur sufficiently because $T_{s}$ of $500^{\circ} \mathrm{C}$ is rather low results in growth of polycrystalline film.

Films of $\mathrm{Cr}_{2} \mathrm{O}_{3}$ having a lattice constant a little bit smaller than that of $\alpha-\mathrm{Fe}_{2} \mathrm{O}_{3}$ were grown onto GGG (111) as well. The films sputtered in atmospheres containing oxygen showed X-ray diffraction spectra similar to those of $\alpha-\mathrm{Fe}_{2} \mathrm{O}_{3}$ films, except that the film at ambient temperature was amorphous, while the film sputtered below $400^{\circ} \mathrm{C}$ in pure Ar exhibited a strong [0006] texture. However, the latter film was considerably oxygen deficient. Figure 4 shows pole figure of the $\mathrm{Cr}_{2} \mathrm{O}_{3}$ film with prominent (0006)-orientation, taken from the (11) 3 ) diffraction peak. It exhibits a pair of spotlike pole densities, which is clearly separated, every $60^{\circ}$ in $\phi$ scans as well as the case of $\alpha-\mathrm{Fe}_{2} \mathrm{O}_{3}$. It is apparent from pole-figure analysis that the orientation relationship between the film and the substrate is the same as that for $\alpha-\mathrm{Fe}_{2} \mathrm{O}_{3}$ film. These results indicate that nearly single crystalline $\mathrm{Cr}_{2} \mathrm{O}_{3}(0001)$ film can be grown in situ onto GGG (111) without an underlying layer, in contrast with the $\alpha-\mathrm{Fe}_{2} \mathrm{O}_{3}$ film.

The above orientation relationship between the films with the corundum structure and the GGG substrate is explained in terms of the close structural fit between the cation sites as reported previously [2]: The arrangement of $\mathrm{Fe}$ ion or $\mathrm{Cr}$ ion in triangular symmetry in the corundum structure roughly fits into the Gd site which is the largest cation site in the garnet structure. In this case, the $[2 \overline{1} 10]$ direction of the corundum structure lies parallel to the [110] direction of the substrate, consistent with the experimental results. However, the in-plane lattice arrangement of the dodecahedraily coordinated Gd and tetrahedrally coordinated Ga in the GGG (111) plane is locally distorted, leading to considerable deviation from the ideal arrangement with triangular symmetry. This gives flexibility to the in-plane orientation of the film, which results in substantial twist misalignment of the grains observed at the $\alpha-\mathrm{Fe}_{2} \mathrm{O}_{3}$ film. The difference in the shape of pole density and epitaxial behavior between the $\alpha-\mathrm{Fe}_{2} \mathrm{O}_{3}$ film and the $\mathrm{Cr}_{2} \mathrm{O}_{3}$ film may be ascribed to a different lattice constant. Further studies on it are required.

\section{CONCLUSION}

We have epitaxially grown $\alpha-\mathrm{Fe}_{2} \mathrm{O}_{3}(0001)$ films and $\mathrm{Cr}_{2} \mathrm{O}_{3}$ (0001) films with the corundum crystal structure in situ on GGG (111) by rf sputtering. It was achieved for $\alpha-\mathrm{Fe}_{2} \mathrm{O}_{3}$ films by a two-step deposition process, which involved an initial growth of $\alpha-\mathrm{Fe}_{2} \mathrm{O}_{3}$ at ambient temperature followed by growth at $500^{\circ} \mathrm{C}$, while, for $\mathrm{Cr}_{2} \mathrm{O}_{3}$ films, by direct deposition. These films were grown with an in-plane alignment of [2î̃10] parallel to GGG [110].

\section{References}

[1] C.A. Carosella, D.B. Chrisey, P. Lubitz, J. S. Horwitz, P. Dorsey, R. Seed and C. Vittoria, J. Appl. Phys. 71 (1992) 5107-5110.

[2] M. Gomi and H. Toyoshima, Jpn. J. Appl. Phys. 35 (1996) L544-L546. 